\title{
UROTHELIAL CARCINOMA AND ITS ASSOCIATION WITH AGE AND GENDER.
}

\footnotetext{
1. MBBS, DCP, M.Phil. Histopathology Senior Lecturer Department of Pathology LUMHS 2. MBBS, FCPS. Assistant professor Department of General Surgery LUMHS

3. MBBS, FCPS Assistant Professor Department of Nephrology LUMHS.

4. MBBS. DMJ (Forensic Medicine) Senior Lecturar Bilawal Medical College, LUHMS Jamshoro.

5. MBBS, DCP, M.Phil. (Anatomy) Senior Lecturar Isra University Hospital Hyd.
}

Correspondence Address: Dr. Rukhsana Parveen Samo Senior Lecturer

Department of Pathology LUMHS.

Article received on: 10/05/2019

Accepted for publication: 30/07/2019

Received after proof reading: $30 / 09 / 2019$

\section{INTRODUCTION}

Urothelial carcinoma (or transitional cell carcinoma(TCC)) of the urinary bladder, the 4th commonest carcinoma among males and the 9th commonest in females in the United states of America, brings about significant mortality and morbidity. ${ }^{1}$ According to AFIP data TCC of bladder is the seventh most frequent malignancy among both males and females and constitutes $93.4 \%$ of all bladder cancers. ${ }^{2}$ In around $75.0 \%-85.0 \%$ bladder cancer cases, the disease remains restricted to mucosa and has a prolonged clinical course with multiple recurrences after local resection without tumor progression. ${ }^{2,3}$ Hence prevalence of bladder malignancy is low in Sri Lanka than other South Asian nations like India $(32 / 1,000,000)$ and Karachi, Pakistan (89/1,000,000), in Delhi, India, the age adjusted bladder malignancy prevalence reaches 58 per $1,000,000.4^{4-6}$ The significant risk factors for urinary bladder carcinoma reported by epidemiologic studies are smoking (cigarette) and work-related exposure to musky amines. ${ }^{7}$ Further risk factors include genetic/ biomarker susceptibility, water pollutants and fluid intake, gender (male), urinary tract infection (inflammation, stone), environmental toxic waste (arsenic), coffee consumption, socioeconomic status, urinary blood fluke infection, disclosure to ionizing radiations, cyclophosphamide, and further medicinal agents. ${ }^{7,8}$ Sex disparities in epidemiology of bladder malignancy have been an attention of current research. ${ }^{9}$ Female subjects seem to have poorer survival and further unfavorable pathology than male patients. Sex variances in mortality associated to bladder malignancy have frequently been reported, which can possibly be somewhat explained by the greater ratio of unfavorable pathology among female cases. ${ }^{9,10}$ Sex variances in bladder 
malignancy epidemiology can possibly be made clear by past-historical, biological, and lifestyle perspectives. First, sex variances in major hormones and in vascularity nearby the bladder can possibly be a related factor. As of a hormonal standpoint, the prevalence of bladder malignancy was exhibited to be greater among postmenopausal as compared to premenopausal females, and aggressive bladder malignances expressed elevated levels of some androgen receptors and estrogen receptor- $\beta$. ${ }^{1,9}$ Patient's gender and age are vital factors in clinical selection for treating urothelial cancer of the bladder, there are no recommendations based on evidence to guide health care experts. ${ }^{1}$ Additionally, the correlation and effect of gender on bladder TCC prevalence, prognosis, staging, and survival are incompetently understood, ${ }^{11}$ and by recent studies, it is recommended that further research should be done to the better understanding for epidemiological risk-factors and differences according to gender. ${ }^{12}$ Therefore this study has been conducted to determine the urothelial carcinoma and its association with age and gender.

\section{MATERIAL AND METHODS}

This retrospective study has been performed at pathology department of Liaquat university of Medical and Health Science. Study duration was one year from January 2016 to December 2016. Four micrometer thick paraffin-embedded and formalin-fixed sections were prepared from transurethral resection of bladder tumor (TURBT) samples of urothelial carcinoma patients and were examined. All the samples were stained with hematoxylin eosin. Non-invasive papillary urothelial neoplasm of low malignant potential, small cell carcinoma, adenocarcinoma, squamous cell carcinoma, and other neoplasms were excluded. Histological grading was categorized as low and high grades. ${ }^{20}$ All the data regarding age, gender and histological grading was collected by self-made proforma. Data analysis was done by SPSS version 20.0. Frequency and percentage were computed for categorical variables like gender site of carcinoma age groups and histological grading. Mean and standard deviation were calculated for numerical variables like age. Chi-square test was applied and a p-value less than 0.05 was considered as significant.

\section{RESULTS}

In this study total 83 cases were enrolled, their mean age was $49.19 \pm 12.33$ years. Males were found in the majority $51(61.4 \%)$ and females were $32(38.6 \%)$. Most common age group was 4660 years among $36(43.4 \%)$ patients, followed by $24(28.9 \%)$ patients were more than 60 years and $23(27.7 \%)$ were within age group of $30-45$ years. Table-I.

According to the histological grading high grade urothelial carcinoma was most common as $65.10 \%$, and low grade and low grade urothelial carcinoma was $34.90 \%$. Figure-1

Urothelial carcinoma was most common in age group of 46-60 years, as out of 36 patients, 24 had low grade and 12 had high grade, out of 23 cases of 30-45 years age group; 13 had low grade and 10 had high grade, while among 24 patients of $>60$ years 17 had low grade and 7 had high grade urothelial malignancy. No significant variance was found according to age of histological grading; p-value 0.568. Males were most common in urothelial malignancy and out of total 51 males 28 had high grade and 23 had low grade urothelial malignancy, while high grade malignancy was significantly higher among females; as out of total 32 females 26 had high grade and only 6 had low grade carcinoma. Table-II

\begin{tabular}{|c|c|}
\hline Basic Characteristics & Numbers/ Percentage \\
\hline \multicolumn{2}{|l|}{ Gender } \\
\hline Male & $51(61.4 \%)$ \\
\hline Female & $32(38.6 \%)$ \\
\hline Total & $83(100.0 \%)$ \\
\hline \multicolumn{2}{|l|}{ Age groups } \\
\hline $30-45$ years & $23(27.7 \%)$ \\
\hline $46-60$ years & $36(43.4 \%)$ \\
\hline$>60$ years & $24(28.9 \%)$ \\
\hline Total & $83(100.0 \%)$ \\
\hline Age $($ mean \pm SD) & $49.19 \pm 12.33$ years \\
\hline
\end{tabular}




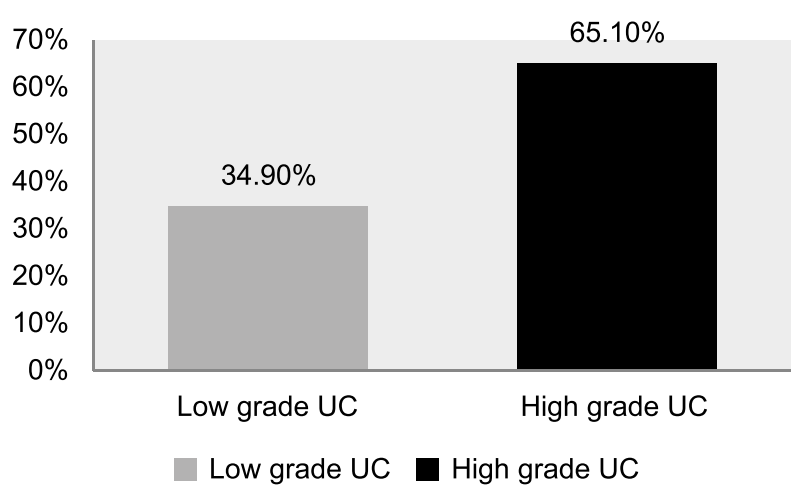

Figure-1. Grading of urothelial carcinoma $\mathbf{n = 8 3}$

\begin{tabular}{|c|c|c|c|c|}
\hline \multirow[b]{2}{*}{ Variables } & \multicolumn{2}{|c|}{ Urothelial carcinoma } & \multirow[b]{2}{*}{ Total } & \multirow[b]{2}{*}{ P-Value } \\
\hline & $\begin{array}{l}\text { High } \\
\text { Grade }\end{array}$ & $\begin{array}{l}\text { Low } \\
\text { Grade }\end{array}$ & & \\
\hline \multicolumn{5}{|l|}{ Age Groups } \\
\hline $30-45$ years & 13 & 10 & 23 & \\
\hline $46-60$ years & 24 & 12 & 36 & 0.568 \\
\hline$>60$ years & 17 & 7 & 24 & \\
\hline Total & 54 & 29 & 83 & \\
\hline \multicolumn{5}{|l|}{ Gender } \\
\hline Male & 28 & 23 & 51 & \\
\hline Female & 26 & 6 & 32 & 0.014 \\
\hline Total & 54 & 29 & 83 & \\
\hline
\end{tabular}

Table-II. Urothelial carcinoma according to age and gender $n=83$

\section{DISCUSSION}

Urothelial carcinoma is a classic pattern of a cancer, emerging from environmental carcinogenic influences. Bladder malignancy is further frequently noted among males, while prognosis is generally worse among females. ${ }^{13}$ In this study males were found in the majority $51(61.4 \%)$ and females were $32(38.6 \%)$, which is similar to the study of Türk $\mathrm{H}$ et al, ${ }^{13}$ which reported that out of five hundred sixty-nine patients, 497 (87.30\%) cases were males and 72 (12.70\%) were females. In recent times, many reviews have summarized and interpreted outcomes from published investigations on the gender disparity in prognosis of bladder malignancy. ${ }^{12-16}$ Multiple factors are suspected to influence the gender specific prognostic outcome.12,16 Distinctive anatomy, deferrals from the earliest symptoms to diagnosis among women, changes in hormone receptors in addition to tumor biology and less ideal treatment for females were proposed to contribute in the observed disparities. ${ }^{17-19}$ Though, even following adjustment for a few of these factors, the gender disparity in survival remained there. ${ }^{12}$ We had suspected another factor for males, as smoking habits are frequent among males in contrast to females, this was also found among many studies that smoking is the commonest factor for urothelial carcinoma. ${ }^{12,14,17}$ It is worth to note in all those studies that the males are most common as compared to females and it is also mentioned that smoking is commonest factor. ${ }^{12,14,17}$ Similarly in this study mostly males had smoking habits.

In this study according to the histological grading high grade urothelial carcinoma was most common as $65.10 \%$. Gupta et $\mathrm{al}^{20}$ also found similar findings as high grade urothelial carcinoma was most common among $55.3 \%$ of the cases. While these findings were inconsistent to the results of Koyuncuer $\mathrm{A}$ et $\mathrm{al}^{8}$, as low grade urothelial carcinoma was observed among 85 $(68 \%)$ of the patients. In many studies these findings were controversial, and this may be because of difference in sample size of the studies or ethnicity. In this series no significant variance was found in age groups in terms of grading of malignancy, while other studies reported that old age is significantly correlated with high grade urothelial malignancy. ${ }^{13,20,21}$ This difference may be because age range was lower in our study in contrast to other studies.

In this study, female ratio was lower involved in urothelial carcinoma, but the progression of disease was significantly higher among females in contrast to males, because high grade urothelial carcinoma was significantly higher among females; as out of 32 women, 26 had high grade malignancy. Similar findings were documented by Sikic $D$ et al. ${ }^{21}$ Among other factors, the expression of estrogen and androgen receptors has been discussed as a possible reason for genderrelated differences. ${ }^{21}$ Shen et al. ${ }^{22}$ observed that the estrogen receptor- $\beta$ is the prevailing receptor expressed in UC of the bladder, and its level of expression raises with progressing tumor grade and stage. With this evidence in mind for the importance of hormone receptors in the formation 
and advancement of UC of the bladder, in mind, one can hypothesize that the hormonal changes that occur after menopause also have an effect on the carcinogenesis of UC. McGrath et al. ${ }^{11}$ showed in a cohort study, that post-menopausal women had a greater risk of acquiring bladder malignancy, moreover, early age at menopause (50 years). While inconsistently Türk $\mathrm{H}$ et $\mathrm{al}^{17}$ reported that there was no significant difference among both genders in terms of tumor stages. According to these controversial ideas of the literature studies, further studies should be done with exclusion of other suspected risk factors for urothelial carcinoma to know the clear association of this malignancy and its progression with gender and age.

\section{CONCLUSION}

It was concluded that male gender is the contributing factor of urothelial carcinoma, but disease progression was significantly high among females. No significant association has been found according to age. Further research is required with exclusion of other risk factors such as smoking and menopausal histories to assess the pure association of gender and age.

\section{Copyright $\subseteq 30$ July, 2019.}

\section{REFERENCES}

1. Shariat SF, Sfakianos JP, Droller MJ, Karakiewicz PI, Meryn $\mathrm{S}$, Bochner $\mathrm{BH}$. The effect of age and gender on bladder cancer: A critical review of the literature. BJU international. 2010 Feb; 105(3):300-8.

2. Atique M, Abbasi MS, Jamal S, Khadim MT, Akhtar $F$, Jamal $N$. CD 10 expression intensity in various grades and stages of urothelial carcinoma of urinary bladder. J Coll Physicians Surg Pak. 2014 May 1; 24(5):351-5.

3. Babjuk M, Oosterlinck W, Sylvester R, Kaasinen E, Böhle A, Palou-Redorta J, et al. European association of urology (EAU). EAU guidelines on non-muscleinvasive urothelial carcinoma of the bladder, the 2011 update. Eur Urol 2011; 59:997-1008.

4. Rastogi T, Devesa S, Mangtani P, Mathew A, Cooper N, Kao R, Sinha R. Cancer incidence rates among South Asians in four geographic regions: India, Singapore, UK and US. International Journal of Epidemiology. 2007 Dec 18; 37(1):147-60.
5. Bhurgri Y, Bhurgri A, Hassan SH, Zaidi SH, Rahim A, Sankaranarayanan R, Parkin DM. Cancer incidence in Karachi, Pakistan: First results from Karachi cancer registry. International journal of cancer. 2000 Feb 1; 85(3):325-9.

6. Sasikumar S, Wijayarathna KS, Karunaratne KA, Gobi U, Pathmeswaran A, Abeygunasekera AM. Pathological characteristics of primary bladder carcinoma treated at a Tertiary Care Hospital and changing demographics of bladder cancer in Sri Lanka. Advances in urology. 2016;2016.

7. Burger M, Catto JW, Dalbagni G, Grossman HB, Herr H, Karakiewicz P, Kassouf W, Kiemeney LA, La Vecchia C, Shariat S, Lotan Y. Epidemiology and risk factors of urothelial bladder cancer. European urology. 2013; 1; 63(2):234-41.

8. Koyuncuer A. Histopathological evaluation of urothelial carcinomas in transurethral resection urinary bladder tumor specimens: Eight years of single center experience. Asian Pacific Journal of Cancer Prevention. 2015; 16(7):2871-7.

9. Zaitsu M, Toyokawa S, Tonooka A, Nakamura F, Takeuchi T, Homma Y, Kobayashi Y. Sex differences in bladder cancer pathology and survival: Analysis of a population $\square$ based cancer registry. Cancer medicine. 2015 Mar; 4(3):363-70.

10. Kirkali Z, Chan T, Manoharan M, Algaba F, Busch C, Cheng L, et al. Bladder cancer: Epidemiology, staging and grading, and diagnosis. Urology. 2005; 66:4-34.

11. McGrath M, Michaud DS, De Vivo I. Hormonal and reproductive factors and the risk of bladder cancer in women. American journal of epidemiology. 2005 Nov $30 ; 163(3): 236-44$.

12. Huang CC, Su YL, Luo HL, Chen YT, Sio TT, Hsu HC, Lai $\mathrm{CH}$. Gender is a significant prognostic factor for upper tract urothelial carcinoma: A large hospitalbased cancer registry study in an endemic area. Frontiers in Oncology. 2019; 9:157.

13. Türk $H$, Ün S, Ergani B. The effect of sex and age differences on pathology results in primary bladder cancer patients. Uroonkoloji Buelteni $=$ Bulletin of Urooncology. 2017; 1; 16(3):81.

14. Zaitsu M, Toyokawa S, Tonooka A, Nakamura F, Takeuchi T, Homma Y, et al. Sex differences in bladder cancer pathology and survival: Analysis of a populationbased cancer registry. Cancer Med 2015; 4(3):363-70.

15. Antoni S, Ferlay J, Soerjomataram I, Znaor A, Jemal A, Bray F. Bladder cancer incidence and mortality: A global overview and recent trends. Eur Urol 2017; 71(1):96-108. 
16. Wolff I, Brookman-May S, May M. Sex difference in presentation and outcomes of bladder cancer: Biological reality or statistical fluke? Curr Opin Urol 2015; 25(5):418-26

17. Dobruch J, Daneshmand S, Fisch M, Lotan Y, Noon AP, Resnick MJ, et al. Gender and bladder cancer: A collaborative review of etiology, biology, and outcomes. Eur Urol 2016; 69(2): 300-10.

18. Thorstenson A, Hagberg O, Ljungberg B, Liedberg F, Jancke $G$, Holmang S, et al. Gender-related differences in urothelial carcinoma of the bladder: A populationbased study from the Swedish National Registry of Urinary Bladder Cancer. Scand J Urol 2016; 50(4):2927.

19. Mitra AP, Skinner EC, Schuckman AK, Quinn DI, Dorff TB, Daneshmand S. Effect of gender on outcomes following radical cystectomy for urothelial carcinoma of the bladder: A critical analysis of 1994 patients. Urol Oncol 2014; 32(1). 521-9
20. Koyuncuer A. Histopathological evaluation of urothelial carcinomas in transurethral resection urinary bladder tumor specimens: Eight years of single center experience. Asian Pacific Journal of Cancer Prevention. 2015; 16(7):2871-7.

21. Sikic D, Wach $S$, Taubert $H$, Richterstetter $M$, Kunath F, Goebell PJ, Schick S, Olbert P, Huber J, Wullich B, Keck $B$. Female gender is an age-dependent negative prognostic factor for patients with upper tract Urothelial carcinoma. Anticancer research. $2015 \mathrm{Jul} 1$; 35(7):4277-81.

22. Shen SS, Smith CL, Hsieh JT, Yu J, Kim IY, Jian W, Sonpavde G, Ayala GE, Younes M, Lerner SP. Expression of estrogen receptors $\square a$ and $\square \beta$ in bladder cancer cell lines and human bladder tumor tissue. Cancer: Interdisciplinary International Journal of the American Cancer Society. 2006 Jun 15; 106(12):2610-6.

\section{AUTHORSHIP AND CONTRIBUTION DECLARATION}

\begin{tabular}{|c|c|c|c|}
\hline Sr. \# & Author-s Full Name & Contribution to the paper & Author's Signature \\
\hline 1 & $\begin{array}{l}\text { Rukhsana Parveen } \\
\text { Samo }\end{array}$ & Principle author & Extar \\
\hline 2 & Nawaz Ali Dal & Co-author & themegarkes \\
\hline 3 & Bhagwan Das & Co- author & \\
\hline 4 & Asiya Parveen Shaikh & Co-author & \\
\hline 5 & Sana Kashif & Co-author & \\
\hline
\end{tabular}

